\title{
UPAYA PENINGKATAN PENGETAHUAN IBU HAMIL DAN SUAMI DI PUSKESMAS PUTRI AYU KOTA JAMBI
}

\author{
Ratu Kusuma \\ Dosen Program Studi Profesi Ners STIKes Baiturrahim Jambi \\ email: ratukusuma1975@gmail.com
}

\begin{abstract}
Lack of knowledge of pregnant women and husband about pregnancy and various things related to pregnancy have a negative influence on the health of the pregnant women, fetus /child, family and community. One effort that can be done by nurses is to provide health education to pregnant women and husband. Puskesmas Putri Ayu is a community health center as partner that has carried out sintegrated antenatal services according to the program, but in its implementation a little pregnant women were accompanied by their husbands when conducting antenatal visit. The target and outcome of community service activities is to increase the knowledge of pregnant women and husband about pregnancy, various needs during pregnancy, various changes that occur during pregnancy and the importance of husband's support for pregnant women. The implementation method used is survey, observation, interview, discussion, and demonstration through health counseling and pregnancy exercises in the prenatal class. This activity was conducted in 3 sessions, followed by 32 pregnant women and 6 husbands. The result of this activity is that most pregnant women who attend antenatal visit are accompanied by sister/parent/aunt, a little pregnant women accompanied by their husbands. The husband's absence is caused by work factor and the assumption that it is better to be accompanied by another parent or sister, and the husband feels ashamed to gather with other pregnant women in the prenatal class. A little husbands were willing to take part in the prenatal class, most of them waited outside after being given counseling, several pregnant women and husband began to understand and actively ask question and express their problems.
\end{abstract}

Keywords: Increased Knowledge, Pregnant Women and Husband

\begin{abstract}
ABSTRAK
Kurangnya pengetahuan ibu hamil dan suami tentang kehamilan dan berbagai hal terkait kehamilan memberikan pengaruh negatif terhadap kesehatan ibu, janin/anak, keluarga dan masyarakat. Salah satu upaya yang dapat dilakukan perawat adalah memberikan pendidikan kesehatan kepada ibu dan suami. Puskesmas Putri Ayu merupakan salah satu mitra yang telah melakukan pelayanan antenatal terpadu sesuai program, namun pada pelaksanaannya hanya sebagian kecil ibu yang didampingi suami saat melakukan kunjungan antenatal. Target dan luaran dari kegiatan pengabdian kepada masyarakat ini adalah meningkatkan pengetahuan ibu dan suami tentang kehamilan, berbagai kebutuhan selama kehamilan, berbagai perubahan yang terjadi selama kehamilan serta pentingnya dukungan suami bagi ibu hamil. Metode pelaksanaan yang digunakan adalah survey, observasi, wawancara, diskusi, tanya jawab dan demonstrasi melalui penyuluhan kesehatan dan senam hamil pada kegiatan Kelas Ibu Hamil. Kegiatan ini dilakukan sebanyak 3 kali pertemuan, diikuti oleh 32 ibu dan 6 orang suami. Hasil dari kegiatan ini adalah sebagian besar ibu hamil yang melakukan kunjungan antenatal didampingi oleh saudara perempuan/orangtua//tante, hanya sebagian kecil ibu yang didampingi suami. Ketidakhadiran suami disebabkan oleh faktor pekerjaan dan anggapan bahwa lebih baik ditemani orangtua atau saudara perempuan lainnya, dan suami merasa malu berkumpul dengan ibu-ibu hamil lainnya dalam Kelas Ibu Hamil. Hanya sebagian kecil suami yang bersedia mengikuti Kelas Ibu Hamil, sebagian besar lainnya menunggu di luar. Setelah diberikan penyuluhan, beberapa ibu dan suami mulai memahami dan aktif bertanya serta mengungkapkan masalah yang dihadapi.
\end{abstract}

Kata Kunci: Peningkatan Pengetahuan; Ibu Hamil dan Suami 


\section{PENDAHULUAN}

Pembangunan kesehatan pada hakekatnya adalah segala upaya yang dilaksanakan oleh semua sektor, yang bertujuan meningkatkan derajat kesehatan masyarakat, untuk itu dilakukan berbagai upaya pelayanan kesehatan masyarakat. Dalam melaksanakan pelayanan yang optimal, diselenggarakan upaya kesehatan dengan pendekatan promotif, preventif, kuratif dan rehabilitatif yang dilaksanakan secara menyeluruh, terpadu dan berkesinambungan. Upaya kesehatan masyarakat adalah setiap kegiatan yang dilakukan oleh pemerintah, swasta, masyarakat dalam upaya memelihara dan meningkatkan kesehatan serta mencegah dan menanggulangi timbulnya masalah kesehatan di masyarakat. Salah satunya upaya tersebut adalah upaya peningkatan kesehatan ibu dan anak melalui pelayanan antenatal terpadu (Kemenkes RI, 2015; Kemenkes RI, 2017).

Upaya kesehatan ibu dan anak adalah upaya di bidang kesehatan yang menyangkut pelayanan dan pemeliharaan kesehatan ibu hamil, ibu bersalin, ibu menyusui, bayi, balita serta anak prasekolah. Gangguan kesehatan yang dialami ibu hamil dapat mempengaruhi kesehatan janin, proses persalinan bahkan dapat mempengaruhi pertumbuhan dan perkembangan pada masa anak dan remaja (Kemenkes RI, 2017).

Pelayanan anternatal terpadu adalah pelayanan antenatal komprehensif dan berkualitas yang diberikan kepada semua ibu hamil yang diberikan oleh tenaga kesehatan yang kompeten yaitu dokter, bidan dan perawat terlatih sesuai dengan ketentuan yang berlaku (Kemenkes RI, 2014). Kualitas antenatal yang diberikan akan mempengaruhi kesehatan ibu hamil dan janinnya, ibu bersalin, bayi baru lahir dan ibu nifas. Pada pelayanan antenatal terpadu, tenaga kesehatan harus dapat memastikan bahwa kehamilan berlangsung normal, mampu mendeteksi dini masalah dan penyakit yang dialami ibu hamil, melakukan intervensi secara adekuat sehingga ibu hamil siap menjalani persalinan normal. Setiap kehamilan mempunyai risiko mengalami penyulit atau komplikasi, oleh karena itu pelayanan antenatal harus dilakukan secara rutin, sesuai standar dan terpadu untuk pelayanan yang berkualitas (Kemenkes RI, 2016).

Tujuan pembangunan kesehatan tersebut tertuang dalam SDGs Tahun 2030, khususnya pada tujuan 3 yaitu tentang kesehatan dan kesejahteraan. Salah satunya adalah dengan target penurunkan Angka Kematian Ibu (AKI) menjadi 70/100.000 kelahiran hidup pada tahun 2030 (Kemenkes RI, 2017). Provisnsi Jambi terdiri dari 11 kabupaten/kota, Kota Jambi merupakan salah satu kabupaten/kota dengan urutan ke-3 AKI tertinggi setelah Kabupaten Merangin dan Bungo (Dinkes Kota Jambi, 2017). Dalam mengatasi masalah tersebut, salah satu upaya yang dapat dilakukan adalah meningkatkan pelayanan antenatal melalui pemberian edukasi khususnya di tingkat pelayanan dasar yaitu puskesmas.

Pusat Kesehatan Masyarakat (Puskesmas) adalah suatu unit fungsional yang berfungsi sebagai pusat pembangunan kesehatan, pusat pembinaan peran serta masyarakat dalam bidang kesehatan serta pusat pelayanan kesehatan tingkat pertama yang menyelenggarakan kegiatan secara menyeluruh, terpadu, berkesinambungan pada suatu masyarakat yang bertempat tinggal dalam suatu wilayah tertentu (Kemenkes RI, 2014).

Puskesmas Putri Ayu merupakan Puskesmas 1 dari 2 puskesmas perawatan yang ada di Kota Jambi. Puskesmas ini beralamat di Jalan Slamet Riyadi nomor 02 Kelurahan Legok Kecamatan Danau Sipin Kota Jambi. Wilayah Kerja Puskesmas Putri Ayu terdiri 5 kelurahan dengan 5 puskemas pembantu yaitu 1) Kelurahan Solok Sipin (Pustu Solok 
Sipin); 2) Kelurahan Murni (tidak memiliki pustu); 3) Kelurahan Sungai Putri (Pustu Sungai Putri); 4) Kelurahan Legok (Pustu Legok dan Pustu Danau Sipin) dan; 5) Kelurahan Danau Sipin.

Puskesmas Putri Ayu didirikan pada tahun 1968, saat ini memiliki tenaga kesehatan yang terdiri dari 2 orang dokter umum, 2 orang dokter gigi, 2 orang sarjana kesehatan masyarakat, 26 orang bidan, 14 orang perawat, 2 orang sanitarian, 1 orang apoteker, 4 orang asisten apoteker, 2 orang analis labor, 3 orang perawat gigi dan 5 orang tenaga non kesehatan yaitu tenaga administrasi umum. Puskesmas Putri Ayu merupakan puskesmas perawatan yang melayani rawat inap selama 24 jam dan melayani persalinan melalui penerapan Asuhan Persalinan Normal sesuai standar. Sebagai salah satu fasilitas pelayanan kesehatan, Puskesmas Putri Ayu memiliki 2 program utama yaitu Program Pokok dan Program Pengembangan Khusus. Program Pokok terdiri dari 5 yaitu: 1) promosi kesehatan; 2) kesehatan ibu dan anak; 3) gizi; 4) kesehatan lingkungan dan 5) pengobatan dasar. Program Pengembangan Khusus juga memiliki 5 program yaitu 1) upaya kesehatan lansia; 2) pelayanan perawatan kesehatan masyarakat (perkesmas); 3) upaya kesehatan mata; 4) upaya kesehatan jiwa; dan 5) upaya kesehatan telinga (Profil Puskesmas Putri Ayu Tahun 2017).

Berdasarkan Profil Puskesmas Putri Ayu (2017), diketahui juga bahwa pada tahun 2017 terdapat 1353 ibu hamil di wilayah kerja Puskesmas Putri Ayu, 100\% ibu hamil tersebut telah melakukan kunjungan antenatal (K1 dan K4) lebih dari 4 kali kunjungan. Namun, ibu yang melakukan persalinan ke tenaga kesehatan hanya 1292 (96\%), artinya terdapat 61 (4\%) persalinan ibu yang ditolong oleh tenaga non kesehatan. Angka ini cukup tinggi, namun tidak bisa dipastikan bahwa $61 \mathrm{ibu}$ tersebut benar-benar melahirkan pada tenaga non kesehatan, bisa saja beberapa ibu melahirkan di luar Kota Jambi, misalnya melahirkan di kampung asal, pindah dari Kota Jambi, dan lain sebagainya.

Berdasarkan survey dan observasi yang dilakukan pada minggu pertama (3-7) September 2018, diketahui bahwa setiap hari rata-rata $15-20 \mathrm{ibu}$ hamil melakukan kunjungan antenatal ke Poliklinik Kesehatan Ibu dan Anak (KIA) Puskesmas Putri Ayu. Sebagian besar ibu hamil yang melakukan kunjungan antenatal tersebut ditemani atau didampingi oleh saudara perempuan/orangtua/tante dan hanya sebagian kecil yang didampingi suami. Observasi senjutnya dilakukan terhadap ibu-ibu hamil yang mengikuti kelas ibu hamil, hasil observasi menunjukkan ratarata 7-10 ibu hamil yang mengikuti kegiatan Kelas Ibu Hamil setiap minggu dan tidak ada suami yang bersedia mengikuti kelas tersebut. Selain observasi, dilakukan juga wawancara terhadap ibu hamil, suami dan keluarga serta tenaga kesehatan di puskesmas tersebut. Hasil wawancara diketahui bahwa ketidakhadiran suami mendampingi ibu melakukan kunjungan antenatal dan Kelas Ibu Hamil adalah karena faktor pekerjaan suami dan adanya persaaan malu bergabung dengan ibu-ibu hamil lainnya dalam mengikuti Kelas Ibu Hamil. Kelas ibu hamil ini adalah kegiatan rutin Puskesmas Putri Ayu, yang dilakukan setiap hari Sabtu pagi.

Dari permasalahan mitra tersebut dapat diketahui bahwa, Puskesmas Putri Ayu telah memberikan Pelayanan Antenatal terpadu sesuai dengan tugas dan peran puskesmas bagi masyarakat. Namun, pelaksanaan berbagai kegiatan tersebut belum maksimal dan masih memiliki keterbatasan baik dari pihak puskesmas maupun masyarakat (ibu hamil dan suami) itu sendiri. Oleh karena itu, tim pengabdian kepada masyarakat ini merasa perlu melakukan upaya promotif dan preventif melalui kegiatan penyuluhan kesehatan kepada ibu hamil dan suami, yang diberikan pada kegiatan Kelas Ibu Hamil yaitu 
setelah pelaksanaa senam hamil.

\section{TARGET DAN LUARAN}

Target dari kegiatan pengabdian ini adalah ibu hamil dan suami di wilayah kerja Puskesmas Putri Ayu yang melakukan kunjungan antenatal dan mengikuti Kelas Ibu Hamil. Luarannya adalah meningkatkan pengetahuan ibu dan suami tentang kehamilan, berbagai kebutuhan selama kehamilan, berbagai perubahan yang terjadi selama kehamilan serta pentingnya dukungan suami.

\section{METODE PELAKSANAAN}

Kegiatan pengabdian kepada masyarakat ini dilakukan di Puskesmas Putri Ayu Kota Jambi, selama 3 bulan yaitu 17 September-17 November 2018. Metode pelaksanaa yang digunakan adalah survey, observasi, wawancara, ceramah, tanya jawab dan demonstrasi dalam bentuk pemberian penyuluhan kesehatan dan senam hamil pada kegiatan Kelas Ibu Hamil. Kegiatan ini dilakukan di Aula Puskesmas Putri Ayu, sebanyak 3 kali pertemuan, diikuti oleh 32 ibu hamil dan 6 orang suami. Materi yang diberikan berbeda-beda pada setiap kali penyuluhan, dengan sebagian peserta yang berbeda-beda juga. Selain mitra dan pelaksana, kegiatan ini dibantu oleh beberapa orang mahasiswa Program Profesi Ners STIKes Baiturrahim Jambi.

\section{HASIL DAN PEMBAHASAN}

Hasil kegiatan pengabdian kepada masyarakat yang telah dilaksanakan dengan mitra Puskesmas Putri Ayu adalah sebagai berikut:

1. Hasil survey dan observasi menunjukkan bahwa sebagian besar ibu hamil yang melakukan kunjungan antenatal ditemani atau didampingi oleh saudara perempuan/orangtua/tante dan hanya sebagian kecil yang didampingi suami.
2. Hasil wawancara menunjukkan bahwa ketidakhadiran suami disebabkan oleh faktor pekerjaan dan anggapan bahwa lebih baik ditemani oleh perempuan misalnya orangtua atau saudara perempuan.

3. Ketidakhadiran suami dalam kegiatan Kelas Ibu Hamil karena suami merasa malu berkumpul dengan ibu-ibu hamil lainnya, sehingga suami memilih menunggu di luar.

4. Hanya sebagian kecil suami yang bersedia mengikuti Kelas Ibu Hamil dan sebagian besar lainnya menunggu di luar.

5. Sebelum diberikan penyuluhan, sebagian besar ibu mengatakan masih kurang paham dengan berbagai macam perubahan yang terjadi selama kehamilan, berbagai kebutuhan ibu selama hamil, serta dampak buruk yang akan timbul akibat kekurangpahaman tersebut. Namun, setelah diberikan penyuluhan, beberapa ibu dan suami mulai memahami dan aktif bertanya serta mengungkapkan masalah yang dihadapi.

6. Setelah pelaksanaan penyuluhan dan Kelas Ibu Hamil, sebagian besar ibu dan suami mulai memahami tentang materimateri yang telah disampaikan, banyak yang memberikan pertanyaan dan mengungkapkan pengalaman yang pernah dialaminya saat hamil.

7. Sebagian besar ibu dan suami menunjukkan sikap positif terhadap pelaksanaan kegiatan penyuluhan dan pelaksanaan Kelas Ibu Hamil.

8. Kegiatan penyuluhan kesehatan ini dilakukan sebanyak 3 kali pertemuan, diikuti oleh 32 ibu hamil dan 6 orang suami.

Masih adanya pertolongan persalinan yang ditolong oleh tenaga non kesehatan merupakan masalah kesehatan yang segera mendapatkan penanganan. Pertolongan persalinan yang ditolong oleh tenaga non kesehatan tidak memperhatikan 
aspek sterilisasi sehingga memperbesar risiko infeksi nifas, yang berdampak buruk bagi ibu dan janin bahkan kematian. Masih terdapatnya beberapa ibu yang melakukan persalinan kepada tenaga non kesehatan di wilayah kerja Puskesmas Putri Ayu ini diduga disebabkan oleh berbagai faktor seperti perilaku (pengetahuan dan sikap) yang dimiliki ibu, suami dan anggota keluarga lainnya sehingga akan mempengaruhi tindakan yang dipilih.

Perilaku kesehatan adalah respons seseorang terhadap stimulus atau objek yang berkaitan dengan sakit dan penyakit, sistem pelayanan kesehatan, makanan dan minuman serta lingkungan. Perilaku kesehatan terdiri dari tiga domain yaitu pengetahuan, sikap dan tindakan (Notoatmodjo, 2010). Menurut teori L. Green dalam Notoatmodjo (2012) terdapat tiga faktor yang mempengaruhi perilaku seseorang yaitu 1) predisposing factors berupa pengetahuan, sikap, kepercayaan, nilai-nilai dan persepsi; 2) enabling factors berupa keterampilan, ketersediaan sumber daya seperti sarana dan prasarana kesehatan seperti rumah sakit, puskesmas, obat-obatan, tenaga kesehatan serta keterjangkauan sumber-sumber tersebut oleh individu atau masyarakat; 3) renforcing factors meliputi sikap dan perilaku tenaga kesehatan atau petugas lainnya, orangtua, tokoh masyarakat, kelompok tertentu, dan lainnya yang menjadi panutan bagi individu atau masyarakat untuk berperilaku.

Dalam hal ini, pengetahuan ibu hamil dan suami tentang kehamilan dan berbagai hal yang terkait dengan kehamilan akan mempengaruhi sikap dan tindakan yang akan dilakukan oleh ibu dan suami. Kurangnya pengetahuan ibu hamil dan suami serta minimnya keikusertaan suami dalam mendampingi ibu hamil melakukan kunjungan antenatal dan Kelas Ibu Hamil di Puskesmas Putri Ayu kemungkinan disebabkan oleh kurangnya pengetahuan ibu,suami dan anggota keluarga lainnya sehingga berdampak kepada pemilihan penolong persalinan kepada tenaga non kesehatan. Faktor lain yang mungkin berkontribusi terhadap pemilihan pertolongan persalinan kepada tenaga non kesehatan tersebut adalah kepercayaan atau nilai yang dimiliki keluarga, kebiasaan dan peran serta anggota keluarga lain seperti orangtua, mertua, saudara, taman, faktor ekonomi terutama bagi ibu/keluarga yang tidak memiliki jaminan kesehatan serta berbagai faktor lainnya. Kurang pengetahuan tersebut berhubungan dengan tingkat pendidikan atau paparan ibu dan suami tentang informasi-informasi terkait kehamilan.

Pelaksanaan kegiatan penyuluhan kesehatan kepada ibu hamil dan suami pada kegiatan pengabdian ini dapat dilihat pada beberapa dokumentasi berikut:
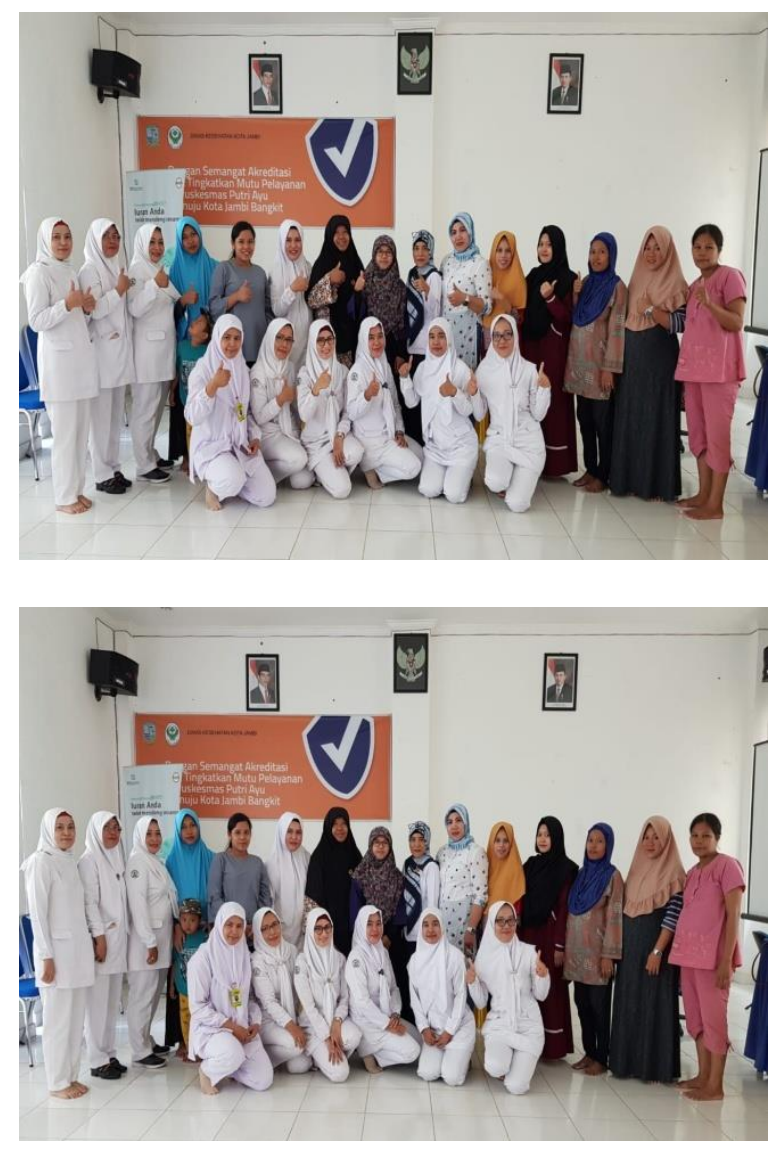

Gambar. 1 dan 2

Tim Pengabmas, Mitra dan Ibu Hamil 

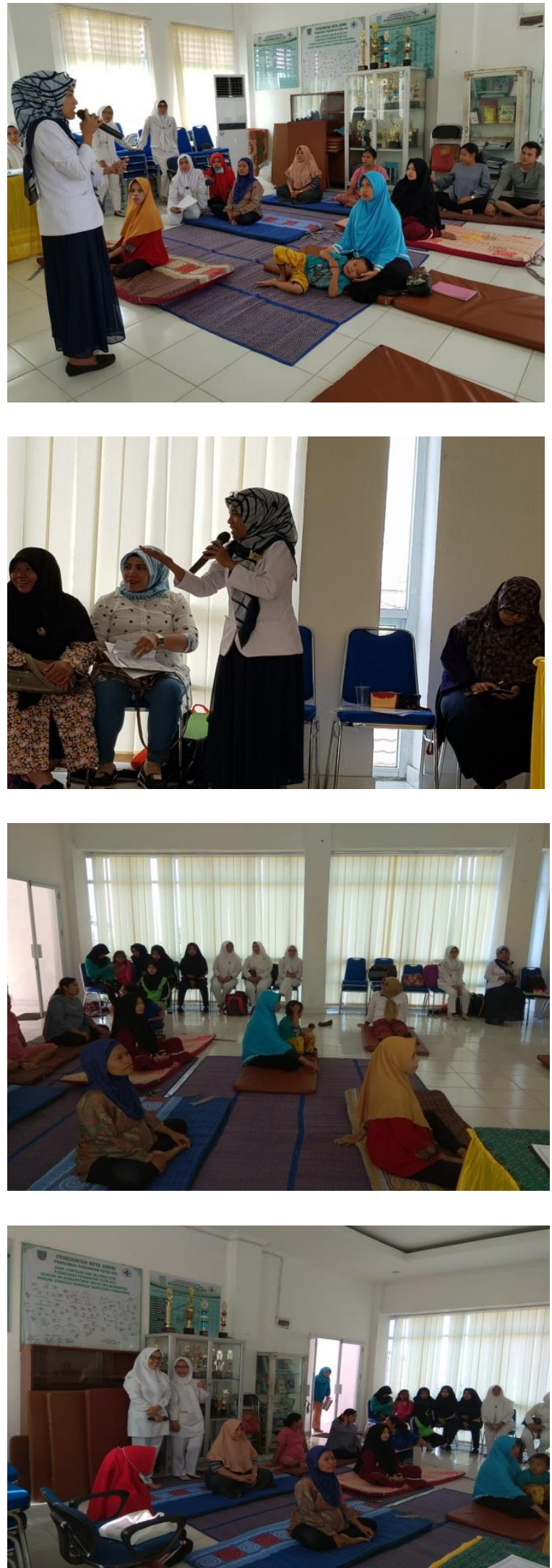

Gambar. 3, 4 dan 5 Pelaksanaan Penyuluhan

\section{KESIMPULAN DAN SARAN}

1. kesimpulan

Secara umum, Puskesmas Putri Ayu telah melakukan pelayanan antenatal sesuai program, namun pada pelaksanaannya, pihak puskesmas mengalami kesulitan untuk menghadirkan suami saat ibu melakukan kunjungan antenatal dan mengajak suami untuk ikut serta dalam kegiatan Kelas Ibu Hamil, sehingga kemungkinan ibu dan suami belum memiliki pengetahuan atau persepsi yang sama terhadap kehamilan, persalinan, postpartum dan lain sebagainya. Diduga, faktor tersebut berdampak terhadap pemilihan pertolongan persalinan ke tenaga non kesehatan.

\section{Saran}

Disarankan kepada petugas kesehatan, khususnya Unit Kesehatan Ibu dan Anak untuk dapat meningkatkan pelayanan antenatal dan melibatkan suami pada setiap kegiatan tersebut, sehingga angka kesakitan dan kematian ibu hamil dapat diturunkan sesuai dengan target yang telah dituangkan dalam tujuan SDGs Tahun 2030.

\section{UCAPAN TERIMA KASIH}

Semua tim dan mitra pada kegiatan pengabdian ini mengucapkan terima kasih kepada:

1. Kepala Dinas Kesehatan Kota Jambi beserta jajarannya.

2. Kepala UPTD Puskesmas Putri Ayu Kota Jambi beserta jajarannya.

3. Mitra dari Puskesmas Putri Ayu terutama penanggung jawab dan pelaksana kegiatan konseling dan Unit KIA.

4. Ketua STIKes Baiturrahim Jambi beserta jajarannya.

5. Mahasiswa Program Profesi Ners STIKes Baiturrahim Jambi. 
6. Semua pihak yang membantu terlaksananya kegiatan ini.

\section{DAFTAR PUSTAKA}

Dinas Kesehatan Provinsi Jambi., 2017. Profil kesehatan provinsi jambi. Jambi: Dinkes Provinsi Jambi.

Glanz, K., Rimer, B.K., \& Viswanath, K., 2008. Health behavior and health education: Theory, research, and practice (4th ed.). San Francisco: Jossey Bass.

Kemenkes, R.I., 2015. Rencana strategi kementerian kesehatan tahun 20152019. Jakarta: Kemenkes, R.I.

Kementerian Kesehatan Republik Indonesia., 2014. Permenkes RI nomor 97 tahun 2014 tentang pelayanan kesehatan masa sebelum hamil, masa hamil, persalinan dan masa sesudah melahirkan, penyelenggaraan pelayanan kontrasepsi, serta pelayanan kesehatan seksual. Jakarta: Kemenkes, R.I.

Kementerian Kesehatan Republik Indonesia., 2014. Permenkes RI nomor 75 tahun 2014 tentang puskesmas. Jakarta: Kemenkes, R.I.

Kementerian Kesehatan Republik Indonesia., 2016. Permenkes RI nomor 43 tahun 2016 tentang standar pelayanan minimal bidang kesehatan. Jakarta: Kemenkes, R.I.

Kementerian Kesehatan Republik Indonesia., 2016. Buku kesehatan ibu dan anak. Jakarta: Kemenkes, R.I.
Kementerian Kesehatan Republik Indonesia., 2017. Sustainable Development Goals (SDGs). Jakarta: Kemenkes, R.I. 